\title{
GENETIC EVALUATION OF SOME EXTRA LONG STAPLE COTTON STRAINS (Gossypium barbadense L.,) UNDER DIFFERENT ENVIRONMENTS
}

\author{
EL-HOSEINY, H. A.
}

\author{
Cotton Research Institute, ARC, Giza, Egypt
}

(Manuscript received 19 June 2013)

\begin{abstract}
This study aimed to clear the interaction between the genotypes and environment on the performance of genotypes. Also to identificy the relationship among the current studied traits and the range of similarity between the genotypes. Thirty-five new cotton strains descending from fourteen Egyptian cotton crosses as well as five check varieties were included in Trial (A) were sown 2011 at Kafr El-Sheikh. According to the data of yield components and fiber traits, twenty strains were selected for sowing in the next season at three locations in trial (B) at 2012 season. With respect to multivariate analysis data four strains, numbered $12,17,19$ and 20 which were derived from [(G. $70 \times$ Pima S6) $\times$ G. $89 \times$ G. 86)], (Pima S7 x G. 92), (G. 67 x Pima S6) x G.92, G.88 x (G.86 x G. 45) genotypes. These genotypes proved to be good substitutes to the genotypes G.87, promising cross $\{[\mathrm{G} .84 \times(\mathrm{G} .70 \times \mathrm{G} .51 \mathrm{~B})] \times \mathrm{S} 62\}$, G.88 and G.93 respectively. Estimation of variance component indicated that genetic components were more important than the components of genetic interaction. Heritability of yield components was relatively high (over $50 \%$ ). The genetic variability was low. Stepwise analysis indicated that boll weight and earliness were the main characters responsible for yield performance. Also the data indicated that the traits fiber length (Upper Half Mean) and fiber strength were the main components for yarn strength.
\end{abstract}

\section{INTRODUCTION}

Hybridization among cotton genotypes, followed by conventional pedigree selection is a predominant method utilized for cotton breeding. In such pedigree system the best $F_{2}$ plants and the best plants within the best lines in the following segregating generations are visually selected. Many investigators stated that visual selection in early segregating generations for yield is inefficient and that the evaluation of some strains in such programs begins from $\mathrm{F}_{5}$ generation and continues, until satisfactory genetic stability is achieved. Many investigators (Mohamed 1991, Mohamed et al 2003 and El_Adly and Eissa 2010) evaluated some strains via two tests, the first test is known as Trial (A), and the second test is the advanced trial, known as Trial (B) in the next season. It should be noted that Trial (B) is usually carried out at several locations so as to study the interaction of these genotypes under different environments. This investigation was carried out to evaluate thirty-five 
strains of fourteen crosses tested in Trial A and twelve crosses tested in Trial B at three locations in order to select the best lines for developing new cotton varieties of high lint yield and high fiber traits.

\section{MATERIALS AND METHODS}

In 2011 and 2012 seasons two field experiments were carried out at the Cotton Research Institute, Agricultural Research Center, Egypt in Trial A and the advanced Trial B. Trial A consisted of forty genotypes, thirty-five lines descending from fourteen crosses, one promising cross $\{[\mathrm{G} .84 \times(\mathrm{G} .70 \times \mathrm{G} .51 \mathrm{~B})] \times \mathrm{S} 62\}$ and four commercial varieties: Giza 93, Giza 92, Giza 87 and Giza 88, as checks (Table 1). Trial A was cultivated at Sakha Experiment Station, Agricultural Research Center, Kafr ElSheikh, Egypt. While, trial B was cultivated at four locations in Lower Egypt i.e. Kafr El-Sheikh, El-Dakahlia and Demiat, in private farms, except Sakha. Each trial consisted of twenty lines descending from twelve crosses and the one promising cross $\{[\mathrm{G} .84 \mathrm{X}$ (G.70 x G.51B)] x S62\} and the four commercial varieties Giza 93, Giza 92, Giza 87 and Giza 88 were used as checks (Table 2).

The experimental design used in trial $A$, and trial $B$, was the randomized complete block design with six replications; each plot consisted of five rows.The row was four meters long, $60 \mathrm{~cm}$ apart, and $20 \mathrm{~cm}$ between hills. Each hill was thinned to two plants per hill. The middle three rows of each plot were harvested to determine the following traits.

1. Seed cotton yield (SCY): estimated as average weight of seed cotton yield in ken/fed, $\left(\right.$ Ken $=157.5 \mathrm{Kg}$ and Fed $\left.=4200 \mathrm{~m}^{2}\right)$.

2. Lint cotton yield (LY): measured as average weight of lint yield in Ken/fed.

3. Boll weight (BW): as the weight of 50 bolls picked randomly.

4. Lint percentage $(L \%)$ : calculated from the formula: Lint percentage $=($ Weight of lint cotton yield in the sample / Weight of seed cotton yield) X 100 .

5. Earliness index (E \%): expressed as yield of the first pick $\times 100 /$ total seed cotton yield.

6. Fiber fineness and maturity (Mic): measured by Micronaire apparatus in Micronaire units.

7. Fiber strength (Stel): expressed as millitex $\left(1^{0-8} \mathrm{~g} / \mathrm{Tex}\right)$.

8. Upper half mean (UHM): determined by the digital Fibrograph.

9. Yarn strength (YST): is the product of "Lea strength $x$ Yarn Count" (60s carded and 3.6 twist multiplier) measured by the Good Brand Tester.

All fiber tests were performed in the Laboratories of the Cotton Technology Research Division, Cotton Research Institute, Agricultural Research Center, Giza. 
Table 1. Origin and pedigree of the studied cotton genotypes (Trial A), 2011 season

\begin{tabular}{|c|c|c|c|}
\hline No. & Parent & Family & Origin \\
\hline 1 & $F_{5} 1173 / 010$ & $\mathrm{~F}_{4} 1095 / 09$ & G. $93 \times$ G.92 \\
\hline 2 & $F_{5} 1177 / 010$ & $\mathrm{~F}_{4} 1100 / 09$ & " \\
\hline 3 & $F_{5} 1179 / 010$ & " " " " & $"$ \\
\hline 4 & $F_{5} 1207 / 010$ & $F_{4} 1139 / 09$ & (G. $45 \times$ Sea Island) $\times$ G.92 \\
\hline 5 & $F_{5} 1213 / 010$ & $F_{4} 1142 / 09$ & G. $93 \times$ Suvin \\
\hline 6 & $F_{5} 1221 / 010$ & $\mathrm{~F}_{4} 1149 / 09$ & " " " \\
\hline 7 & $F_{5} 1222 / 010$ & " " " " & " " " " \\
\hline 8 & $\mathrm{~F}_{5} 1228 / 010$ & $F_{4} 1159 / 09$ & " " " \\
\hline 9 & $\mathrm{~F}_{6} 1248 / 010$ & $F_{5} 1176 / 09$ & $($ G. 70 x Pima S6 ) x G. 92 \\
\hline 10 & $\mathrm{~F}_{6} 1250 / 010$ & " " " " & " " " " \\
\hline 11 & $\mathrm{~F}_{6} 1254 / 010$ & $F_{5} 1178 / 09$ & " " " " \\
\hline 12 & $\mathrm{~F}_{6} 1266 / 010$ & $F_{5} 1198 / 09$ & (G. $70 \times$ Pima S6 ) $\times$ Pima high lint $\%$ \\
\hline 13 & $\mathrm{~F}_{6} 1274 / 010$ & $F_{5} 1200 / 09$ & " " " " \\
\hline 14 & $\mathrm{~F}_{6} 1275 / 010$ & " " " " & " " " \\
\hline 15 & $\mathrm{~F}_{6} 1282 / 010$ & $F_{5} 1208 / 09$ & (G. $70 \times$ Pima S6 ) $\times($ G. $89 \times$ G. 86) \\
\hline 16 & $\mathrm{~F}_{6} 1288 / 010$ & $F_{5} 1215 / 010$ & " " " " \\
\hline 17 & $F_{6} 1291 / 010$ & $F_{5} 1219 / 09$ & " " " " \\
\hline 18 & $\mathrm{~F}_{6} 1307 / 010$ & $F_{5} 1232 / 09$ & G. $88 \times$ Pima S6 \\
\hline 19 & $F_{6} 1310 / 010$ & " " " " & " " " \\
\hline 20 & $\mathrm{~F}_{6} 1321 / 010$ & $F_{5} 1245 / 09$ & " " " " \\
\hline 21 & $\mathrm{~F}_{6} 1322 / 010$ & " " " " & " " " \\
\hline 22 & $F_{7} 1331 / 010$ & $F_{6} 1257 / 09$ & Pima S7 x G. 45 \\
\hline 23 & $F_{7} 1333 / 010$ & " " " " & " " " \\
\hline 24 & $F_{7} 1342 / 010$ & $F_{6} 1270 / 09$ & Pima S7 x G.76 \\
\hline 25 & $\mathrm{~F}_{7} 1344 / 010$ & " " " " & " " " " \\
\hline 26 & $F_{7} 1358 / 010$ & $F_{6} 1276 / 09$ & " " " " \\
\hline 27 & $F_{7} 1359 / 010$ & " " " " & " " " \\
\hline 28 & $F_{7} 1370 / 010$ & $F_{6} 1290 / 09$ & Pima S7 x G.92 \\
\hline 29 & $F_{7} 1372 / 010$ & $F_{6} 1291 / 09$ & " " " " \\
\hline 30 & $F_{7} 1377 / 010$ & $F_{6} 1302 / 09$ & " " " \\
\hline 31 & $\mathrm{~F}_{8} 1386 / 010$ & $F_{7} 1321 / 09$ & (G. 67 x Pima S6) x G. 92 \\
\hline 32 & $F_{8} 1393 / 010$ & $F_{7} 1333 / 09$ & " " " " \\
\hline 33 & $F_{9} 1396 / 010$ & $F_{8} 1338 / 09$ & G. $88 \times($ G. $68 \times$ G.45) \\
\hline 34 & $F_{9} 1398 / 010$ & " " " & " " " \\
\hline 35 & $F_{9} 1403 / 010$ & $F_{8} 1348 / 09$ & " \\
\hline 36 & \multicolumn{2}{|c|}{$[$ G. $84 \times(G .70 \times$ G.51B $)] \times$ S62 } & $\{[\mathrm{G} .84 \times(\mathrm{G} .70 \times \mathrm{G} .51 \mathrm{~B})] \times \mathrm{S} 62\}$ \\
\hline 37 & \multicolumn{2}{|c|}{ Giza 93} & (G. 77 x Pima S6 ) \\
\hline 38 & \multicolumn{2}{|c|}{ Giza 92} & [G.84 x (G.74 x G.68)] \\
\hline 39 & \multicolumn{2}{|c|}{ Giza 87} & G. 77 x G.45 \\
\hline 40 & \multicolumn{2}{|c|}{ Giza 88} & G.77 x G.45 \\
\hline
\end{tabular}


Table 2. Origin and pedigree of the studied cotton genotypes (Trial B), 2012 season

\begin{tabular}{|c|c|c|c|}
\hline No & Genotypes & Parent & Origin \\
\hline 1 & $F_{5} 1173 / 010$ & $F_{4} 1095 / 09$ & G. $93 \times$ G. 92 \\
\hline 2 & $F_{5} 1177 / 010$ & $F_{4} 1100 / 09$ & " " " " \\
\hline 3 & $F_{5} 1179 / 010$ & " " " " & " " " \\
\hline 4 & $F_{5} 1207 / 010$ & $F_{4} 1139 / 09$ & (G. $45 \times$ Sea Island) $\times$ G.92 \\
\hline 5 & $F_{5} 1222 / 010$ & $\mathrm{~F}_{4} 1149 / 09$ & G. $93 \times$ Suvin \\
\hline 6 & $\mathrm{~F}_{5} 1228 / 010$ & $F_{4} 1159 / 09$ & " " " \\
\hline 7 & $F_{6} 1248 / 010$ & $F_{5} 1176 / 09$ & (G. $70 \times$ Pima S6) $\times$ G. 92 \\
\hline 8 & $F_{6} 1254 / 010$ & $F_{5} 1178 / 09$ & $"$ \\
\hline 9 & $F_{6} 1266 / 010$ & $F_{5} 1198 / 09$ & (G. $70 \times$ Pima S6) $\times$ Pima high lint\% \\
\hline 10 & $F_{6} 1275 / 010$ & $"$ & $"$ \\
\hline 11 & $F_{6} 1288 / 010$ & $\mathrm{~F}_{5} 1215 / 09$ & (G. $70 \times$ Pima S6) $\times($ G. $89 \times$ G. 86$)$ \\
\hline 12 & $F_{6} 1291 / 010$ & $F_{5} 1219 / 010$ & " " " \\
\hline 13 & $F_{6} 1322 / 010$ & " " " " & " " " \\
\hline 14 & $\mathrm{~F}_{7} 1331 / 010$ & $F_{6} 1257 / 09$ & Pima S7 x G. 45 \\
\hline 15 & $F_{7} 1342 / 010$ & $F_{6} 1270 / 09$ & Pima S7 x G.76 \\
\hline 16 & $\mathrm{~F}_{7} 1358 / 010$ & $F_{6} 1276 / 09$ & " " " \\
\hline 17 & $F_{7} 1370 / 010$ & $F_{6} 1290 / 09$ & Pima S7 x G.92 \\
\hline 18 & $F_{8} 1386 / 010$ & $F_{7} 1321 / 09$ & (G. 67 x Pima S6) x G. 92 \\
\hline 19 & $F_{8} 1393 / 010$ & $F_{7} 1333 / 09$ & $"$ \\
\hline 20 & $F_{9} 1396 / 010$ & $F_{8} 1338 / 09$ & $\mathrm{G} .88 \times(\mathrm{G} .68 \times \mathrm{G} .45)$ \\
\hline 21 & \multicolumn{2}{|c|}{$[\mathrm{G} .84 \times(\mathrm{G} .70 \times \mathrm{G} .51 \mathrm{~B})] \times \mathrm{S} 62$} & $\{[\mathrm{G} .84 \times(\mathrm{G} .70 \times \mathrm{G} .51 \mathrm{~B})] \times \mathrm{S} 62\}$ \\
\hline 22 & \multicolumn{2}{|c|}{ Giza 93} & (G. $77 \times$ Pima S6 ) \\
\hline 23 & \multicolumn{2}{|c|}{ Giza 92} & {$[\mathrm{G} .84 \times(\mathrm{G} .74 \times \mathrm{G} .68)]$} \\
\hline 24 & \multicolumn{2}{|c|}{ Giza 87} & G.77 x G.45 \\
\hline 25 & \multicolumn{2}{|c|}{ Giza 88} & G. $77 \times$ G. 45 \\
\hline
\end{tabular}

The analysis of variance was performed according to Sendecor (1965).

Table 3. Form of the analysis of variance and expectations of mean squares for a single environment

\begin{tabular}{|c|c|c|c|}
\hline S.O.V. & d.f & M.S & E.M.S \\
\hline Replications & $r-1$ & & \\
Genotypes & $g-1$ & $M_{2}$ & $\sigma^{2} e+r \sigma^{2} g$ \\
Error & $(r-1)(g-1)$ & $M_{1}$ & $\sigma^{2} e$ \\
\hline
\end{tabular}




\section{Where:}

$R, g, M_{1}, M_{2}, \sigma^{2} e, \sigma^{2} g$ : number of replications, number of genotypes, error mean squares, genotypes mean squares, error variance and genotypic variance, respectively.

Table 4. Form of the combined analysis of variances and expectations of mean squares for all genotypes over environments

\begin{tabular}{|l|c|l|l|}
\hline \multicolumn{1}{|c|}{ S.O.V. } & d.f & M.S & \multicolumn{1}{|c|}{ E.M.S } \\
\hline Environments(E) & $\mathrm{L}-1$ & & \\
Replications/ L & $\mathrm{L}(\mathrm{r}-1)$ & & \\
Genotypes & $\mathrm{g}-1$ & $\mathrm{M}_{3}$ & $\sigma^{2} \mathrm{e}+\mathrm{r} \sigma^{2} \mathrm{~g} \mathrm{~L}+\mathrm{rL} \sigma^{2} \mathrm{~g}$ \\
Genotypes x E & $(\mathrm{g}-1)(\mathrm{L}-1)$ & $\mathrm{M}_{2}$ & $\sigma^{2} \mathrm{e}+\mathrm{r} \sigma^{2} \mathrm{gL}$ \\
Error & $\mathrm{L}(\mathrm{g}-1)(\mathrm{r}-1)$ & $\mathrm{M}_{1}$ & $\sigma^{2} \mathrm{e}$ \\
\hline
\end{tabular}

\section{Where:}

$\mathrm{E}: \mathrm{r}$ and $\mathrm{g}$ : environments, replications and genotypes, respectively.

$M_{1}, M_{2}$ and $M_{3}$ : are errors, genotypes by environments interactions and genotypes variances, respectively.

Heritability estimated, in broad sense $\left(\mathrm{h}^{2}{ }_{\text {bs }} \%\right)$ was calculated by using the formula:-

$$
h^{2}{ }_{b s} \%=\left[\sigma^{2} g /\left(\sigma^{2} g+\sigma^{2} g e+\sigma^{2} e\right)\right] \times 100
$$

Where: $\sigma^{2} \mathrm{~g}$ : genotypic variance component.

$\sigma^{2} \mathrm{ge}$ : variance component due to genotype $\mathrm{x}$ environment.

The cluster analysis was performed using the group average linkage Euclidean distance and lined by Anderberg (1973). All the previous estimates were performed by using SPSS computer programs (1995). Stepwise multiple regression analysis was carried out according to Draper and Smith (1966) to determine the best variables accounted for most variance in seed and lint cotton yield and yarn strength.

\section{RESULTS AND DISCUSSION}

Table (5) shows the variance analysis of 35 strains as well as the five check varieties. The data indicated the differences of the strains for seed and lint cotton yield and earliness while the boll weight exhibited insignificant difference for strains and varieties.

Table 5. The analysis of variance mean squares for Trial A in Sakha, 2011 season

\begin{tabular}{|c|c|c|c|c|c|}
\hline S.O.V. & d.f & b.w & $\begin{array}{c}\text { Seed cotton } \\
\text { yield K/F }\end{array}$ & $\begin{array}{c}\text { Lint cotton } \\
\text { yield K/F }\end{array}$ & Earlieness \% \\
\hline Replications & 5 & 39.21 & 24.54 & 30.76 & 162.33 \\
\hline Genotypes & 39 & 21.80 & $14.08^{*}$ & $19.50 *$ & $30054 *$ \\
\hline Error & 195 & 16.75 & 3.72 & 4.6 & 103.87 \\
\hline
\end{tabular}

*,** significantly different at the 0.05 and 0.01 levels of probability, respectively

With regard to the yield the data Table (6) showed that 17 out of 35 genotypes surpassed the overall means of total genotypes. 
Table 6. Mean performance for yield and its components and fiber properties of genotypes in Trial A in Sakha

\begin{tabular}{|c|c|c|c|c|c|c|c|c|c|}
\hline No & S.C.Y. & Lint $Y$. & Lint \% & BW & E \% & UHM & F.St & Mic & $\begin{array}{c}\text { Yarn } \\
\text { St. }\end{array}$ \\
\hline 1 & 13.79 & 15.2 & 35.0 & 150 & 59.96 & 35.9 & 45.9 & 3.3 & 3180 \\
\hline 2 & 12.3 & 13.66 & 35.27 & 145 & 56.63 & 36.8 & 46.5 & 3.5 & 2970 \\
\hline 3 & 13.11 & 14.47 & 35.04 & 150 & 43.11 & 36.2 & 44.5 & 3.6 & 2995 \\
\hline 4 & 12.71 & 13.86 & 34.62 & 148 & 52.34 & 34.7 & 42.3 & 3.5 & 2840 \\
\hline 5 & 10.6 & 11.67 & 34.97 & 150 & 37.04 & 34.7 & 43.7 & 3.3 & 2945 \\
\hline 6 & 12.56 & 13.3 & 33.64 & 150 & 52.96 & 36.2 & 43.1 & 3.4 & 2950 \\
\hline 7 & 13.70 & 14.19 & 32.88 & 147 & 42.28 & 36.5 & 46.0 & 3.6 & 3045 \\
\hline 8 & 12.96 & 14.03 & 34.36 & 155 & 47.11 & 35.0 & 45.2 & 3.9 & 2945 \\
\hline 9 & 12.68 & 14.05 & 35.18 & 149 & 56.04 & 34.8 & 45.2 & 3.7 & 2965 \\
\hline 10 & 11.7 & 12.69 & 34.42 & 151 & 60.86 & 35.1 & 46.7 & 3.9 & 2960 \\
\hline 11 & 13.06 & 13.67 & 33.24 & 153 & 54.61 & 36.7 & 46.3 & 3.8 & 3115 \\
\hline 12 & 13.12 & 14.31 & 34.64 & 152 & 57.29 & 36.5 & 48.5 & 3.8 & 3185 \\
\hline 13 & 10.14 & 10.82 & 33.9 & 145 & 55.94 & 37.6 & 44.0 & 3.9 & 2960 \\
\hline 14 & 11.75 & 12.89 & 34.82 & 150 & 48.13 & 37.3 & 45.0 & 4.0 & 3190 \\
\hline 15 & 9.45 & 10.86 & 36.48 & 151 & 34.75 & 36.5 & 42.4 & 4.0 & 2900 \\
\hline 16 & 11.28 & 12.95 & 36.44 & 152 & 46.8 & 38.1 & 45.8 & 4.0 & 3195 \\
\hline 17 & 11.55 & 12.5 & 34.38 & 153 & 48.84 & 36.4 & 43.6 & 4.0 & 3020 \\
\hline 18 & 9.91 & 11.25 & 36.06 & 151 & 38.47 & 38.1 & 44.5 & 3.9 & 3050 \\
\hline 19 & 10.95 & 12.75 & 36.97 & 149 & 43.52 & 35.9 & 44.0 & 3.9 & 3030 \\
\hline 20 & 11.81 & 13.22 & 35.78 & 149 & 47.82 & 38.5 & 43.8 & 4.0 & 2980 \\
\hline 21 & 11.79 & 13.71 & 36.7 & 152 & 52.02 & 37.2 & 48.5 & 4.0 & 3080 \\
\hline 22 & 9.70 & 10.37 & 34.55 & 150 & 42.41 & 37.1 & 45.5 & 3.7 & 3075 \\
\hline 23 & 8.79 & 9.48 & 34.13 & 150 & 40.84 & 38.6 & 45.8 & 3.8 & 3175 \\
\hline 24 & 11.33 & 13.2 & 36.29 & 151 & 43.18 & 34.7 & 41.7 & 3.6 & 2880 \\
\hline 25 & 9.35 & 10.95 & 37.17 & 152 & 38.67 & 35.2 & 42.0 & 3.7 & 2955 \\
\hline 26 & 8.90 & 10.2 & 36.39 & 150 & 37.68 & 36.0 & 43.5 & 3.7 & 2980 \\
\hline 27 & 8.53 & 9.14 & 34.03 & 151 & 42.18 & 37.4 & 45.6 & 3.8 & 2875 \\
\hline 28 & 13.12 & 15.12 & 36.59 & 150 & 41.18 & 35.2 & 46.9 & 4 & 2950 \\
\hline 29 & 13.88 & 15.82 & 36.19 & 151 & 55.25 & 34.1 & 40.1 & 4 & 2785 \\
\hline 30 & 12.64 & 13.82 & 34.72 & 151 & 48.2 & 36.3 & 45.6 & 4 & 2850 \\
\hline 31 & 11.16 & 11.89 & 33.81 & 152 & 49.39 & 37.8 & 44.6 & 3.9 & 2690 \\
\hline 32 & 11.56 & 13.33 & 36.61 & 151 & 49.34 & 35.5 & 40.2 & 3.7 & 2965 \\
\hline 33 & 12.05 & 13.83 & 36.46 & 150 & 44.5 & 37.3 & 43.3 & 4 & 2535 \\
\hline 34 & 11.66 & 13.45 & 36.62 & 151 & 43.22 & 35.9 & 44.3 & 4.3 & 2695 \\
\hline 35 & 11.05 & 13.11 & 37.66 & 151 & 38.87 & 37.6 & 44.5 & 4.2 & 2750 \\
\hline 36 & 13.54 & 17.04 & 39.97 & 147 & 43.84 & 36.0 & 46.6 & 4.1 & 3545 \\
\hline 37 & 11.43 & 12.38 & 34.4 & 150 & 46.05 & 36.5 & 44.5 & 3.0 & 2660 \\
\hline 38 & 12.79 & 14.67 & 36.4 & 151 & 56.49 & 33.5 & 43.8 & 3.7 & 2825 \\
\hline 39 & 8.48 & 8.94 & 33.48 & 149 & 34.73 & 36.0 & 40.5 & 3.5 & 2755 \\
\hline 40 & 10.47 & 12.22 & 37.06 & 149 & 45.19 & 36.2 & 46.2 & 4.0 & 2965 \\
\hline Mean & 11.53 & 12.88 & 35.43 & 150 & 46.94 & 36.3 & 44.5 & 3.8 & 2935 \\
\hline L.S.D. $5 \%$ & 2.39 & 2.66 & & 5.07 & 12.63 & & & & \\
\hline L.S.D. $1 \%$ & 3.15 & 3.50 & & 6.68 & 16.63 & & & & \\
\hline
\end{tabular}


The data also indicated that 14 out 35 exhibited mean performance of lint percentage surpassed the overall mean, while genotypes which exhibited mean performance of genotypes number 25 and 35 for lint \% were superior than the variety G. 88 .

With regard to the quality traits, the data indicated that the ranges of these traits were 34.7 to 37.6 , from 40.1 to $46.7,3.3$ to 4 and from 2785 to 3195 for upper half mean, fiber strength, micronaire and yarn strength respectively. Regarding the data of 19 genotypes, were selected for evaluation in trial B at three locations.

Table (7) showed the combined analysis of 19 selected strain as well as the five check cultivars at three locations for yield and its components.

The data suggested that the mean squares of genetic and location were highly significant for yield, boll weight and earliness index. The data also showed that the interaction between genotypes and environment were significant. With regard to the mean performance of yield and its component and fiber properties presented in (Table 8) the results indicated the ranges of $(7.79-11.16),(8.36-12.35)$, (33.21 - 38.28), $(147-153)$ and $(58.83-71.53)$ for seed cotton yield, lint yield, lint percentage and earliness index, respectively. Advanced strain number 20 of G.88 x (G. 68 x G.45) recorded the highest yield potential. It was followed by the promising hybrid which was isolated strain and genotypes number 19, 17, and 12 with insignificant differences with regard to lint percentage, the strains exhibited higher lint percentage. Also these strains did not differ significantly for earliness index.

Table 7. Form of the combined analysis of variances and expectations of mean squares for all genotypes over environments

\begin{tabular}{|l|c|c|c|c|c|}
\hline \multicolumn{1}{|c|}{ S.O.V. } & d.f & b.w & $\begin{array}{c}\text { Seed cotton } \\
\text { yield K/F }\end{array}$ & $\begin{array}{c}\text { Lint cotton } \\
\text { yield K/F }\end{array}$ & Earlieness \% \\
\hline Environments(E) & 2 & 2205.9 & 1489.2 & 1777.8 & 32504.7 \\
\hline Replications/ L & 15 & 24.16 & 17.4 & 21.064 & 830.2 \\
\hline Genotypes & 24 & $184.19 *$ & $10.75^{*}$ & $14.9 *$ & $235.5^{*}$ \\
\hline Genotypes x E & 48 & 56.3 & 6.40 & 7.0 & 81.5 \\
\hline Error & 360 & 29.8 & 3.6 & 4.4 & 72.6 \\
\hline
\end{tabular}

$*, * *$ significantly different at the 0.05 and 0.01 levels of probability, respectively

With regard to fiber quality, the derived strains exhibited similar level to extralong cultivars. The mean performance of differ traits showed differences with range of $(37.2-35.2)$, (3.1- 4.0), (46.3 - 49.1) for upper half mean, micronaire value, and fiber strength while yarn strength the derived strains exhibited insignificant differences. The highest mean values of upper half mean and finniest micronaire reading were recorded by cultivars Giza 93, while the derived strains from cross G.88 x (G.68 x G.45) exhibited higher upper half mean and a micronaire value of 3.8 and fiber strength of 46.6. Therefore the best four derived strain were numbered with 12 , $17,19,20$ as well as isolated promising cross $\{[\mathrm{G} .84 \times(\mathrm{G} .70 \times \mathrm{G} .51 \mathrm{~B})] \times \mathrm{S} 62\}$. 
Table 8. Mean performance for yield and its components and fiber properties of genotypes in Trial (B) at four locations

\begin{tabular}{|c|c|c|c|c|c|c|c|c|c|}
\hline No & S.C.Y & L.C.Y & $\begin{array}{l}\text { Lint } \\
\%\end{array}$ & B.W & E \% & F.L & MIC & F.S & $\begin{array}{c}\text { Yarn } \\
\text { St }\end{array}$ \\
\hline 1 & 10.09 & 11.11 & 35.25 & 149 & 65.81 & 35.8 & 3.8 & 49 & 3193 \\
\hline 2 & 9.89 & 10.78 & 34.64 & 147 & 66.32 & 35.3 & 3.8 & 47.7 & 3188 \\
\hline 3 & 9.40 & 10.28 & 34.74 & 147 & 66.28 & 35.5 & 3.8 & 46.9 & 3105 \\
\hline 4 & 10.07 & 10.86 & 34.60 & 150 & 70.80 & 35.2 & 3.8 & 49.1 & 3198 \\
\hline 5 & 10.00 & 10.46 & 33.37 & 151 & 71.67 & 35.9 & 3.8 & 49.2 & 3207 \\
\hline 6 & 10.31 & 10.95 & 33.60 & 153 & 70.17 & 35.2 & 3.8 & 49.1 & 3110 \\
\hline 7 & 9.48 & 10.35 & 34.66 & 152 & 67.02 & 35.2 & 3.8 & 47.9 & 3102 \\
\hline 8 & 10.76 & 11.52 & 33.97 & 152 & 71.53 & 36.3 & 3.8 & 49.1 & 3227 \\
\hline 9 & 10.67 & 11.24 & 33.49 & 153 & 71.19 & 36.1 & 4 & 47.9 & 3163 \\
\hline 10 & 10.00 & 10.83 & 34.30 & 152 & 58.83 & 36.1 & 4 & 47.4 & 3135 \\
\hline 11 & 9.37 & 10.40 & 35.16 & 152 & 65.17 & 36.5 & 4 & 47.4 & 3185 \\
\hline 12 & 10.53 & 11.18 & 33.72 & 153 & 64.39 & 36.1 & 3.9 & 45.9 & 3110 \\
\hline 13 & 9.70 & 10.85 & 35.60 & 154 & 64.00 & 35.6 & 3.9 & 47.5 & 3108 \\
\hline 14 & 7.79 & 8.36 & 33.93 & 148 & 62.73 & 35.5 & 4 & 46.9 & 3108 \\
\hline 15 & 10.39 & 11.53 & 35.30 & 151 & 67.62 & 36.4 & 3.9 & 48.5 & 3123 \\
\hline 16 & 8.71 & 9.75 & 35.46 & 153 & 63.82 & 36.2 & 3.9 & 47.1 & 3173 \\
\hline 17 & 10.21 & 11.40 & 35.33 & 152 & 62.54 & 35.4 & 4 & 46.7 & 3142 \\
\hline 18 & 9.02 & 9.61 & 33.86 & 153 & 69.20 & 36.1 & 3.8 & 47.5 & 3150 \\
\hline 19 & 9.99 & 11.09 & 35.23 & 153 & 69.86 & 35.4 & 3.8 & 49.5 & 3210 \\
\hline 20 & 11.16 & 12.35 & 35.09 & 152 & 65.30 & 37.2 & 3.8 & 46.4 & 3190 \\
\hline 21 & 9.54 & 11.52 & 38.28 & 151 & 60.30 & 35.4 & 4 & 46.6 & 3137 \\
\hline 22 & 10.18 & 10.99 & 34.41 & 153 & 67.54 & 36.8 & 3.1 & 46.3 & 3172 \\
\hline 23 & 10.05 & 11.23 & 35.54 & 151 & 71.02 & 34.9 & 3.8 & 46.8 & 3065 \\
\hline 24 & 8.28 & 8.66 & 33.21 & 153 & 62.32 & 35.4 & 3.7 & 46.5 & 3112 \\
\hline 25 & 8.50 & 11.98 & 35.84 & 153 & 62.84 & 36.8 & 3.9 & 48.7 & 3212 \\
\hline Mean & 9.76 & 10.77 & 34.74 & 151.4 & 66.33 & 35.9 & 3.8 & 47.7 & 3153 \\
\hline L.S.D. $5 \%$ & 1.20 & 1.33 & & 3.45 & 5.39 & & & & \\
\hline L/S.D. $1 \%$ & 1.20 & 1.33 & & 3.45 & 5.39 & & & & \\
\hline
\end{tabular}




\section{Similarity and taxonomic distance}

The best four derived as well as the cultivars $\{[\mathrm{G} .84 \times(\mathrm{G} .70 \times \mathrm{G} .51 \mathrm{~B})] \times \mathrm{S} 62\}$, G.93, G.92, G.87, G88 were used in hierarchical cluster to determine the relative similarity and diversity or taxonomic distance with regard to the above mentioned results. The best four lines were represented by $F_{6} 1291 / 2010$ belonging to cross (G. $70 \times$ Pima s6 ) x (G.89 x G.86), $F_{7} 1370 / 010$ belonging to cross (Pima s7 x G.92, F81393/010 belonging to cross (G. $67 \times$ Pima s6 ) x G.92, $F_{9} 1396 / 010$ belonging to cross G.88 x ( G.68 x G.45). These four lines as well as the four cultivars. G.93, G.92, G87 and G.88 in addition the promising cross $\{[\mathrm{G} .84 \times(\mathrm{G} .70 \times \mathrm{G} .51 \mathrm{~B})] \times \mathrm{S} 62\}$ were used in hierarchical cluster to determine the relative similarity and diversity or taxonomic distance

The linkage dendrogram provides visual idea about clustering and variability among the oboe mentioned entries. Figure (1) and Table (9) showed that the studies entries were divided at distance level 45.59 with similarity level of $69.04 \%$ into two group the first group represented by cultivars G.92 the second groups represented by the rest genotypes and cultivar. The groups was divided into two subgroups at distance level 30.5 with similarity level of $79.29 \%$

The first sub groups by $12\left(F_{6}\right.$ 1291/010) and cultivars $G .88$ exhibited similarity level of $96.90 \%$ as sub-sub grouped and other sub-sub group repressed by $17\left(F_{7} 1370 / 010\right)$ and promising cross $\{[G .84 \times(G .70 \times$ G.51B) $] \times$ S62 $\}$ with similarity of $95.7 \%$ and distance level 6.34 . the second sub groups as follow $19\left(F_{8} 1393 / 010\right)$ and G.88 with similarity level of $94.17 \%$ and distance level 7.70 and other group represented by genotypes $20\left(F_{9} 1396 / 010\right)$ and Giza 93 with similarity level of $87.59 \%$ with distance level 18.27

Table 9. Euclidean method for nine genotypes including two groups for genotypes, distance and similarity for yield and fiber characters.

\begin{tabular}{|c|c|c|c|c|c|}
\hline \multirow{2}{*}{ Node } & \multicolumn{2}{|c|}{ Cluster joined } & \multirow{2}{*}{ Similarity\% } & \multirow{2}{*}{ Distance } & \multirow{2}{*}{ No. of obs. } \\
\hline & Group 1 & Group 2 & & & \\
\hline 1 & 12 & 24 & 96.90 & 4.566 & 2 \\
\hline 2 & 17 & 21 & 95.70 & 6.340 & 2 \\
\hline 3 & 19 & 25 & 94.77 & 7.699 & 2 \\
\hline 4 & 20 & 22 & 87.59 & 18.274 & 2 \\
\hline 5 & Node 3 & Node 4 & 85.80 & 20.919 & 4 \\
\hline 6 & Node 1 & Node 2 & 82.44 & 25.858 & 4 \\
\hline 7 & Node 6 & Node 5 & 79.29 & 30.495 & 8 \\
\hline 8 & Node 7 & 23 & 69.04 & 45.593 & 9 \\
\hline
\end{tabular}




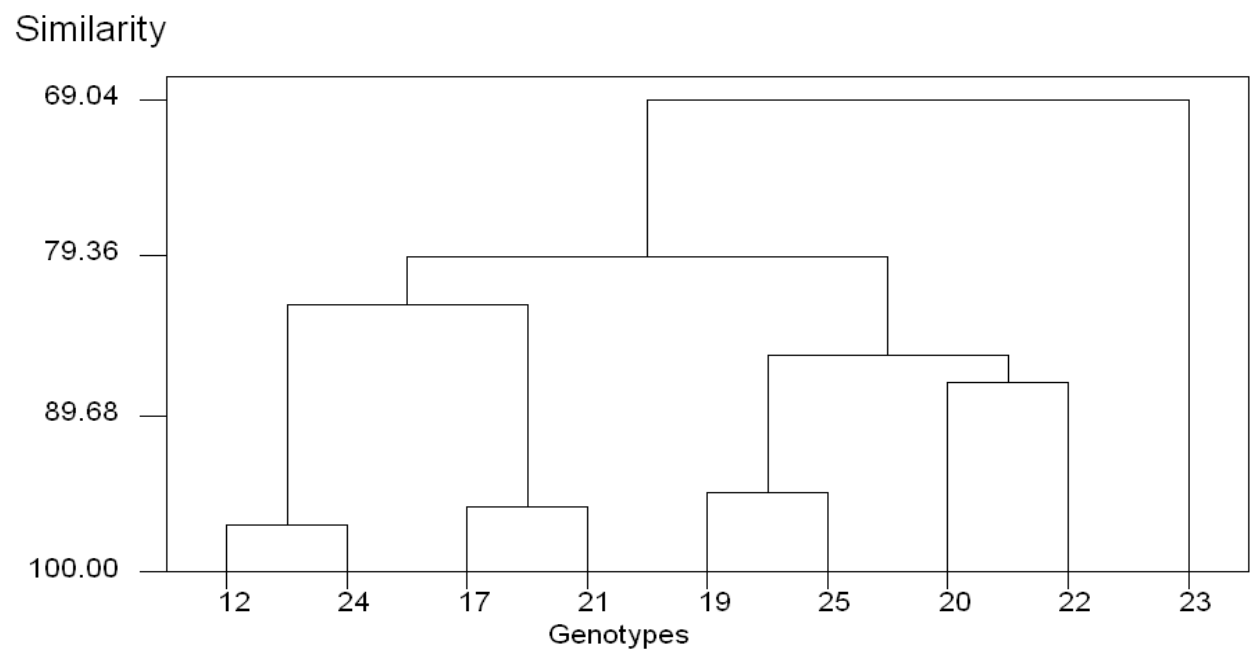

Fig. 1. Dendrogram of taxonomic similarity of nine extra-long cotton genotypes

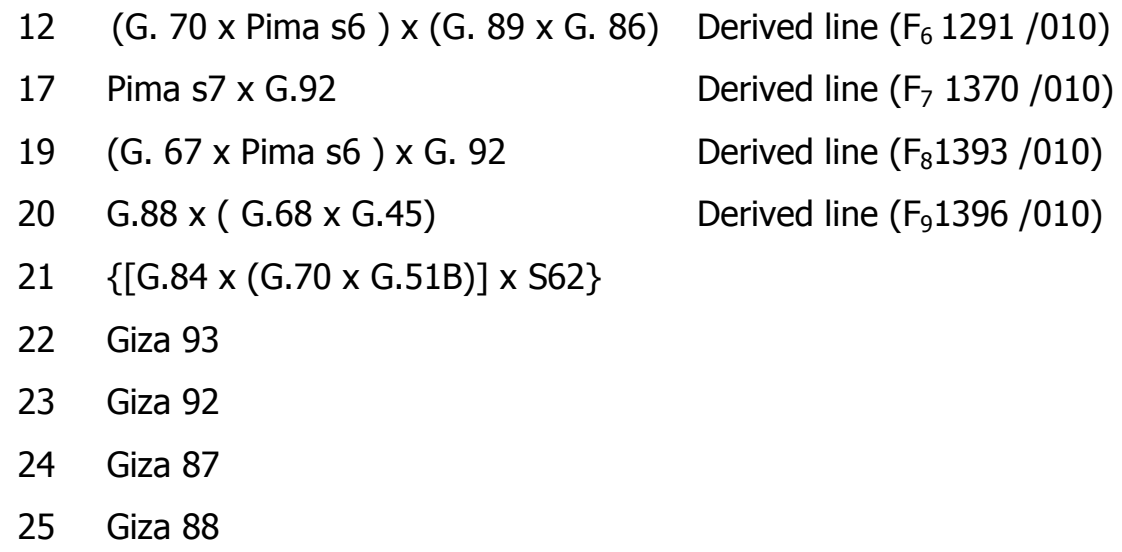

\section{Estimates of variance components and heritability}

Estimates of variance components and their standard error, heritability and genotypic variability (GCV) for yield and its components are presented in Table (10). The data indicated the presence of substantial amount of genetic variance for boll weight, seed cotton yield, lint yield and earliness index. These results agreed with those obtained by Gutierre and EL- Zik (1992), EL-Feki et al., (1995) and Sultan (2012) . Also the results showed that all traits exhibited significant genotypes $x$ environment interaction variance ( $\sigma 2 \mathrm{ge}$ ) the results agreed with those obtained by EL-Feki et al., (1995) and Sultan (2012).

With regard to the ratio $\sigma 2 \mathrm{~g} / \sigma 2 \mathrm{ge}$ presented in Table (6) the results indicated high ratios. Thus these traits were controlled by heritable system/ The data in Table (10) indicated that the heritability value (over $50 \%$ ) for all yield and its components and earliness index. These results agreed with those obtained by Iqbal 
et al. (2011) who revealed that estimates of heritability for boll weight, seed cotton yield and lint percentage were high. Sultan (2012) obtained moderate values of heritability for seed cotton yield and lint yield.

The genotypic variability coefficient (GCV \%) is important in plant breeding since it helps in the assessment of the range of genetic variability in traits and helps in comparing the genetic variance of various traits (Johanson et al. 1955).

Table 10. genetic components and genetic variability and heritability for yield and its component

\begin{tabular}{|c|c|c|c|c|}
\hline & B.w & $\begin{array}{c}\text { Seed cotton yield } \\
\mathrm{K} / \mathrm{F}\end{array}$ & $\begin{array}{c}\text { Lint cotton yield } \\
\mathrm{K} / \mathrm{F}\end{array}$ & Earlieness \% \\
\hline$\sigma^{2} \mathrm{~g}$ & $0.8526 \pm 0.0369$ & $0.0290 \pm 0.0068$ & $0.0527 \pm 0.0092$ & $1.0267 \pm 0.0405$ \\
\hline$\sigma^{2} \mathrm{ge}$ & $0.1767 \pm 0.00280$ & $0.0187 \pm 0.00091$ & $0.0173 \pm 0.00088$ & $0.0593 \pm 0.00162$ \\
\hline$\sigma^{2} \mathrm{~g} / \sigma^{2} \mathrm{ge}$ & 4.826 & 1.554 & 3.038 & 17.303 \\
\hline Heritability (bs) & 82.84 & 60.84 & 75.24 & 94.54 \\
\hline G.C.V \% & 0.563 & 0.297 & 0.489 & 1.548 \\
\hline
\end{tabular}

The GCV\% values are shown in Table (10). The data indicated that boll weight, seed cotton yield and lint yield exhibited low value of GCV \%. Burton (1952) , suggested that genetic coefficient of variability together with heritability estimate gave the best picture of advance expected from selection. Sultan (2012) obtained moderate value of GCV \% for seed cotton yield and lint yield.

\section{Prediction of seed, lint yield and yarn strength}

The regression analysis of variance presented in Table (11). The results indicated that the four variables model was the best equation to determine the prediction of seed cotton and lint yield because they had highly significant mean variance in trial $A$. The equation determining the prediction of yarn strength depends upon three variable.

Table 11. The analysis of variance for multi-regression of accepted variables according to stepwise regression analysis.

\begin{tabular}{|c|c|c|c|c|c|}
\hline & & \multicolumn{2}{|c|}{ A } & \multicolumn{2}{c|}{ B } \\
\hline \multirow{2}{*}{ Variable } & Variance & d.f & M.s & d.f & M.s \\
\hline \multirow{2}{*}{$\begin{array}{c}\text { Seed cotton } \\
\text { yield K/F }\end{array}$} & Regression & 4 & 9.126 & 4 & 0.8730 \\
\cline { 2 - 6 } & Residual & 35 & 1.572 & 20 & 0.6081 \\
\hline \multirow{2}{*}{$\begin{array}{c}\text { Lint cotton } \\
\text { yield K/F }\end{array}$} & Regression & 4 & 14.796 & 4 & 1.7396 \\
\cline { 2 - 7 } & Residual & 35 & 1.931 & 20 & 0.6657 \\
\hline \multirow{3}{*}{ Yarn strength } & Regression & 3 & 95786 & 3 & 8874.6 \\
\cline { 2 - 6 } & Residual & 36 & 27196 & 21 & 966.2 \\
\hline
\end{tabular}


For trial B the data in Table (11) showed that the four variable mode for seed and lint cotton yield were not the best equation to determine the prediction of seed and lint cotton yield because they had insignificant values so it could be found the other variable in this equation Table (12) shows the regression equation for predicting seed and lint cotton yield in trial $(A)$ the regression equation of seed yield and lint yield, respectively, are:

SCY $=-9.8+0.118 X_{1}+0.0546 X_{2}+0.108 X_{3}-0.004 X_{4}$

$L C Y=-28.8+0.499 X_{1}+0.103 X_{2}+0.0950 X_{3}-0.0 .73 X_{4}$

The data in Table (12) showed that the earliness index was more important for predicting seed cotton yield and followed by boll weight while agreed with those obtained in trial $(A)$. While, from lint cotton yield the data indicated that boll weight was more important and followed by lint percentage although this equation was not the best equation.

For yarn strength the best equation was as follow

Yarn strength $=666+39.0 \mathrm{X}_{5}-18.7 \mathrm{X}_{6}+24.1 \mathrm{X}_{7}$

The data in Table (12) showed that the earliness index was more important in predicting the seed cotton yield. While, for prediction are lint yield, the boll weight and earliness index were more important to predict the lint cotton yield.

Table 12 .The best regression equation for predicting seed cotton yield, lint cotton yield and yarn strength in two trials $A$ and $B$.

\begin{tabular}{|l|c|c|c|c|c|c|}
\hline \multirow{2}{*}{ Variable } & \multicolumn{3}{|c|}{ A } & \multicolumn{3}{c|}{ B } \\
\cline { 2 - 7 } & $\begin{array}{c}\text { Seed } \\
\text { cotton } \\
\text { yield K/F }\end{array}$ & $\begin{array}{c}\text { Lint cotton } \\
\text { yield K/F }\end{array}$ & $\begin{array}{c}\text { Yarn } \\
\text { strength }\end{array}$ & $\begin{array}{c}\text { Seed cotton } \\
\text { yield K/F }\end{array}$ & $\begin{array}{c}\text { Lint cotton } \\
\text { yield K/F }\end{array}$ & $\begin{array}{c}\text { Yarn } \\
\text { strength }\end{array}$ \\
\hline Constant & -7.38 & -20.81 & 995.9 & -9.76 & -28.79 & 665.8 \\
\hline Boll weight & 0.2252 & 0.6311 & - & 0.1181 & 0.4987 & - \\
\hline Lint \% & 0.0360 & 0.0345 & - & 0.05464 & 0.10330 & - \\
\hline Earliness \% & 0.14114 & 0.15729 & - & 0.10790 & 0.09502 & - \\
\hline Mic & -0.2896 & -0.3253 & 1.71 & -0.0042 & 0.0727 & 39.36 \\
\hline U.H.M & - & - & 42.90 & - & - & -18.70 \\
\hline $\begin{array}{l}\text { Fiber } \\
\text { strength }\end{array}$ & - & - & -1.9 & - & - & 24.081 \\
\hline
\end{tabular}

The final regression equation of seed cotton yield, lint cotton yield and lea product (yarn strength) respectively are:-

$$
\begin{aligned}
& \text { SCY }=-7.4+0.225 X_{1}+0.036 X_{2}+0.141 X_{3}-0.290 X_{4} \\
& \text { LCY }=-20.08+0.631 X_{1}+0.034 X_{2}+0.157 X_{3}-0.325 X_{4} \\
& \text { Yarn strength }=995.9+1.7 X_{3}+42.9 X_{6}-2.0 X_{7}
\end{aligned}
$$


According to aforementioned equation of the bulk of total variance in seed cotton yield in Trial (A) was attributed to earliness index followed by boll weight. While lint yield was attributed to boll weight and followed by earliness index. These results were partially in harmony with those obtained by Ismail et al. (1994) who reported that a number of bolls per plant followed by boll weight were the major contributors to seed and lint yield and these results agreed with those obtained by ElFeki et al. 2002 for yarn strength in Trial (A).

From the obvious results, it many be summarized that the major cause of differences among genotypes in relation to production stabilities is the genotypes $\mathrm{x}$ environment (GE) interaction, so that the performance of the genotypes depends on the specific environmental conditions this explained the part of genotypes $x$ environment interaction. While, the most of GE interaction cannot be explained by the major factor of environment.

Also the results identified that the relationships among the current studied traits, is very important and this gives the breeder a highly useful tool for planning a breeding program by providing relevant information on the potential gains that will be achieved as the breeding process advances.

The results identified that genotypes [(G. $70 \times$ Pima S6) x G. $89 \times$ G. 86)], (Pima S7 x G.92), (G. $67 \times$ Pima S6) x G.92, G.88 x (G.86 x G. 45) could replace varieties G.87, promising cross $\{[\mathrm{G} .84 \times(\mathrm{G} .70 \times \mathrm{G} .51 \mathrm{~B})] \times \mathrm{S} 62\}, \mathrm{G} .88$ and $\mathrm{G} .93$ in future respectively.

\section{REFERENCES}

1. Anderberg, M.R. 1973. Cluster analysis for applications. Academic Press, New York.

2. ASTM, 1998. (Designation D.4605 - 98 and 3818- 98) Vol. 07. No 1 Easton, MD, USA.

3. Burton, G.W. 1982. Quantitative inheritance in grass. Proc. $6^{\text {th }}$ Int. Grassland Congr. 1: 227 - 283. C.F. Gupta, S.P., T.H. Singh and P.S. Phul. 1972. Indian J. Agric. Sci. 42 (3): 215 - 218.

4. Draper, N.R. and H. Smith 1966. Applied regression analysis John wiley and Sons, Inx., New York- pp 407.

5. El-Adly, H. H. and E. A. M. Eissa. 2010. Estimate of genotypic variance and covariance components in some Egyptian cotton genotypes. Egypt. J. of, Appl. Sci. 25 (3): 80-90. 
6. El-Feki, T.A., Hanaa F. Fahamy, Sayeda S. El-Helw and G.M.I. Emam. 1995. Genetic analysis of lint yield and lint quality characters for Egyptian cotton extralong staple genotypes. Egypt. J. Appl. Sci. 10 (9): 575 - 587.

7. El-Feki, T.A., M.A.A. Nagib; Sayeda S. El-Helw and M.A.M. Allam. 2002. The prediction for seed cotton and lint yield in different generations of cross cotton. Minia J. of Agric. Res. \& Develop. 22 (4): $369-380$.

8. Gutierre, J. C. and K.M. El-Zik. 1992. Genotype $x$ environmental interaction of upland cotton yield, earliness and fiber quality traits in Spain. Beltwide Conference cotton Egypt. J. Appl. Sci. 5(7): 390 - 409.

9. Iqbal, M. Khan, M. Jameel., M.M. Yar., Q. Javed., M.T. Aslam., B. Iqbal, Sara Shakir and A. Ahamed 2011. Study of heritable variation and genetics of yield and yield components in upland cotton (Gossypium hirsutum L.). Afr. J. Agric. 6 (17): $4099-4103$.

10. Ismail, M.Q., E.M. Ghoneim and Alia, A. El-Seondy 1994. Stepwise regression analysis for the determination of some major variables in Egyptian cotton yield. Egypt J. Appl. Sci.; 9- (3) $361-368$.

11. Johanson, H.W., H.F., Robinson and R.E. Comstock 1955. Estimates of genetic and environmental variability in soybeans. Agron. J. 47: $314-318$.

12. Mohamed, S. A. S. 1991. Evaluation of some cotton hybrids for earliness and yield components. M.Sc. Thesis, Fac. Agric., Al-Azhar Univ., Egypt.

13. Mohamed, S. A. S., H. H. El-Adly and A. E. M. Eissa. 2003. Evaluation of some Egyptian cotton genotypes under different environments. Egypt. J. Agri. Res. 81 (4):1997-1816.

14. Snedecor, G. W. 1965. Statistical Methods. Iowa Stat Univ. |Press, Ames, Iowa, U.S.A.

15. Sultan, Aziza M. 2012 genetic analysis and evaluation of some extra-long staple Egyptian cotton genotypes. 


\title{
التقييم الور اثى لبعض سلالات القطن فائقة الطول تحت بيئات مختلفة
}

\author{
حسن امين الحسينى \\ معهُ بحوث القطن - مركز البحوث الزراعية - الجيزة - مصر
}

يهدف هذا البحث الى تقييم 35 سلالة ناتجة من 14 هجين مقارنة بأربعة أصناف منزرعة

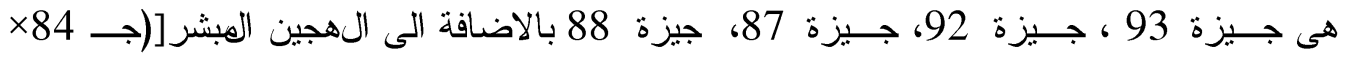

(جـ70× جـ 51ب) × س 62] اختبرت فى تجربة المحصول الاولية ( أ ) لقسم بحوث تربية القطن حيث زرعت هذه التجربة فى محطة البحوث الزر اعية بسخا موسم 2011م ومن نتائج المحصول و التيلة لهذه التجربة نم انتخاب 20سلالة بالاضافة الى الاصناف المقارنة و الهجين المبشر

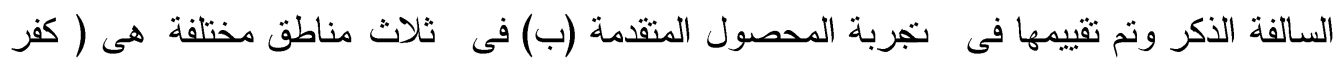
الثيخ، الدقهلية، دمياط، ) للموسم الزر اعى لثئ 2012م.

كانت الصفات المدروسة هى محصول الزهر ، ومحصول الثعر وتصافى الحليج و التبكير

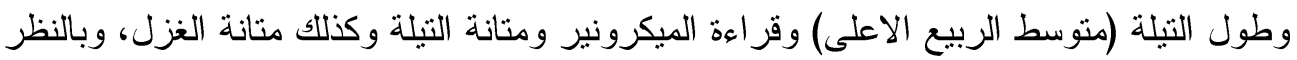

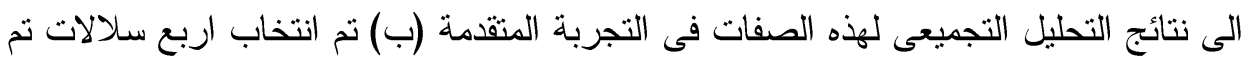
ادخالها فى تحليل التقسيم الهرمى لبيان مدى تثابه هذه السلالات مع الاصناف التى يمكن ان تحل لهل محلها وكانت النتائج كالاتى - اوضحت النتائج ان افضل التزاكيب الور اثية هى التزاكيب رقم 12، 17، 19 ، 20 فى تجربة

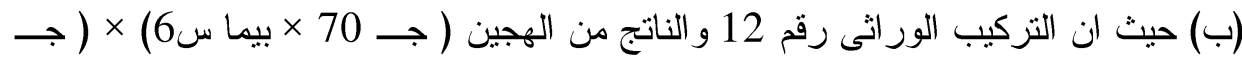

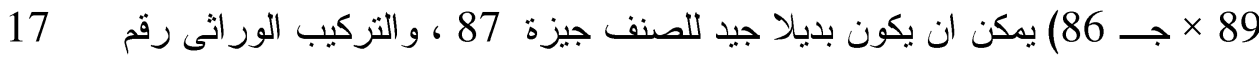

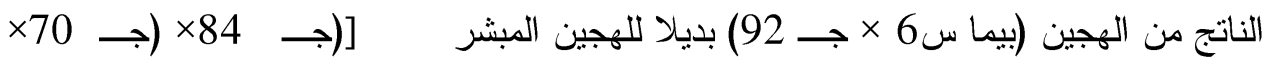

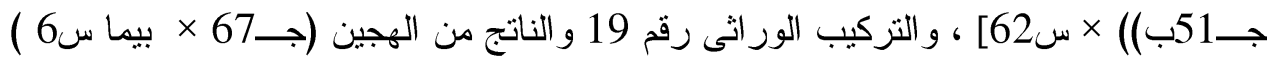

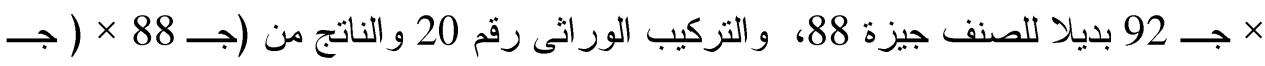
68 × جـ 45) بديلا للصنف جيزة 93. - - اثنار تحليل التباين الى ان المكون الوراثى اكثر اهمية من التفاعل بين البيئة و الور اثذة فى توريث صفات المحصول ومكوناته - كانت درجة التوريث اكبر من 50\% بينما كانت قيم معامل الاختلاف الور اثي اقل القيم.

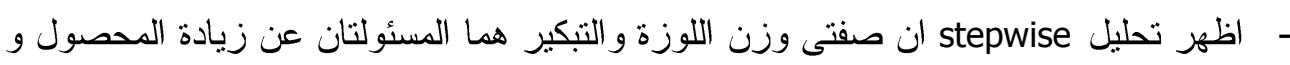
ان صفتى طول التيلة ومتانة التيلة كانتا اهم الصفات المسئولة عن متانة الغزل. 